\title{
State Obligations in Public Health Governance
}

\author{
DengJiaheng $^{1}$ \\ ${ }^{1}$ Law . Chengdu University of Technology Chengdu China
}

\begin{abstract}
This paper mainly analyzes state obligations in global public health governance under the outbreak of 2019-nCoV.In the age of information technology, public health incidents have shifted from those within a nation into a global problem. Based on an analysis of the content of state obligations in the global public health governance mechanism, this paper further discusses the shortcomings of the mechanism and the reasons for them. Finally, the paper puts forward solutions for how to deal with the public health crisis in the context of globalization, in order to provide better solutions when countries implement public health governance.
\end{abstract}

\section{State Obligations in Global Health Governance Mechanism}

\subsection{Content of State Obligations}

State obligations fall into two levels: the first level refers to a country's obligations to the international community as a whole, which means: These obligations are essential for safeguarding the basic ethics and common value of the human society and are the international obligations targeting the whole international community. In the UN Convention they are expressed in the form of noninterference in the internal jurisdiction of other states and respect for the territorial sovereignty independence and territorial integrity of states. The second level of state obligations refers to a nation's obligation to its own citizens within its own border [1]. Moreover, it is the obligation of the state to protect the rights of citizens. The origin of international obligations is also diverse, and it is mostly related to the origin of International Law. For example, international obligations will grow out of international common practices, international treaties, and the principles of International Law.

\subsection{State Obligations Under International Law in the Modern System}

Public health crisis has become a global agenda rather than a security issue within a country with globalization. The governance mechanism of methodological nationalism has already been outdated. All countries should assume the obligations of governance under the background of globalization and undertaken responsibilities in International Law.

The International Sanitary Regulations and the World Health Organization have set out state obligations in the international prevention and control of infectious diseases.
Their purpose is to "prevent the international transmission of diseases with minimal disruption to international traffic". Under this purpose, state obligations fall into the following two aspects: The first aspect is the obligations of all countriess themselves. Firstly, all nations have full obligations of notification. This requires member states to timely notify the WHO on their outbreak of plague, cholera, and yellow fever. Secondly, all nations have the obligation to prevent and control infectious diseases. This requires all countries to set up essential epidemic prevention institutions and health facilities at airports and ports to prevent the outbreak of infectious diseases. This also requires all countries to take control measures against the three categories of infectious diseases stipulated in the regulations to prevent the further spread of an outbreak [2]. Finally, the obligation to impose minimum interference on international traffic. The purpose of this regulation is to prevent epidemic control measures in a country from affecting international traffic. The second aspect is the cooperation obligations of member states in the WHO. State cooperation in prevention and control shall not be restricted by national borders and sovereignty.

\subsection{State Obligations in Global Public Health Governance}

\subsubsection{Constitution in the World Health Organization and State Obligations}

In 1946, after much gaming mediation of interests, the World Health Organization Charter was adopted by the World Health Assembly, marking the establishment of the World Health Organization. At this time, the pattern of world health governance shifted from the formulation of the quarantine system by European developed countries to prevent the introduction of diseases from developing countries in Asia, Africa, and Latin America. (b) To govern global health issues for the world. 
This shift is also associated with the change in the definition of the right to health. According to the Constitution of the World Health Organization, the functions of the WHO include: set normative standards, provide assistance and advice on medical affairs, and advocate changes in health policies. With the release of "Achieving health for all" in 1977 and changes in human understanding on diseases, the WHO started to be engaged in not only the technical medical field but also the political. The definition of health offered by the WHO is "a state of complete physical, mental and social well-being and not merely the absence of disease or infirmity." Meanwhile, it also extended the right to health to human right protection and advocated the protection of this right through the comprehensive participation of multiple sectors such as economic and social departments. Therefore, the state and the government should be responsible for the right to health of their people and the country should construct basic medical infrastructure and adopt effective laws and policies [3]. More importantly, the definition has prompted the international community to recognize the importance of the right to health from the perspective of the shared interest of human beings and called for global cooperation in safeguarding public health. From the objective of the World Health Organization set out in Chapter I of the Constitution of the World Health Organization - "the attainment by all peoples of the highest level of health standard", all countries in the world have the obligation to secure the overall health interest of human beings through international cooperation.

\subsubsection{International Health Regulations and state obligations}

International Health Regulations is another legal document enacted by the World Health Organization. It is the only legally binding legal document on controlling infectious diseases around the world. Based on the international human rights mechanism, its 2005 revised version set out a larger number of more rigorous obligations for member states. In addition to limiting the spread of infectious diseases around the world and mitigating the impact on the international commercial system, it also took human rights protection and environmental safety as the target of "integrated governance". This not only shows that global public health governance has been "securitized", but also proves the importance of international cooperation towards disease containment. This has challenged the traditional concept of state sovereignty. Article 5 and Article 13 indicate that States Parties should develop and strengthen core detection and response capabilities. This is different from the concept in the $19^{\text {th }}$ century that all countries can prevent cross-border transmission as long as they enhance epidemic prevention along their border. Therefore, States Parties are obliged to enable the WHO to intervene in their public health governance within its own sovereignty, which enables States Parties to control the outbreak of epidemic from the source [4].

However, though it contains provisions on states' obligations on supervision, notification, and construction, it is impossible to implement them overnight. Among them, the important reason lies in the imbalance of core abilities. The shortage in capital, personnel, technology, and environment of developing and developed countries can easily paralyze the health infrastructure, thereby disabling some developing countries from well coping with the challenges of the global epidemic. However, based on the consideration of their own interest, developed countries are reluctant to provide capital and technical support to developing areas. Also, International Health Regulations (2005) contains provisions on the obligation of contracting states to assume the obligations of providing capital and technical support, which has enabled the global public health governance system to often lose its response capacity in handling an epidemic on a large scale [5].

Additionally, International Health Regulations (2005) has not only reflected the principle of human rights but also stipulated that "human dignity, human right, and fundamental freedom should be fully respected in the implementation of these regulations." However, western countries mostly advocate the protection of human rights and would even forsake public security owing to human rights,as we can see in Article 5 of the 1950 European Convention on Human Rights and Article 21 of the European Social Charter.These conventions are nonhierarchical and often cause conflicts in safeguarding human rights and controlling the spread of epidemic . If all States Parties cannot integrate human rights considerations with the governance system of public health, then the provisions on safeguarding human rights in IHR (2005) in keeping with the times would not have served their original purpose.

\subsection{WTO and State Obligations in Public Health Governance}

Trade has long been connected with public health. The earliest "quarantine" measures to deal with infectious diseases were taken on the basis of a measure of economic efficiency. The object of quarantine at that time was also one of the means of transport for merchant ships.

The World Trade Organization originated from the General Agreement on Tariffs and Trade (GATT) in 1947. It is one of the pillars of global economic development. Its main objective is to coordinate and promote the free trade of the world. However, free trade would sometimes exert a negative impact on public health governance. In the case of monopoly, unrestricted free trade will exacerbate the uneven distribution of resources among countries leading monopolists to ignore public health in pursuing economic interest. For example, the imbalance between the protection of patent rights and the drug access between the developing and the developed countries in TRIPS enables it to be inclined to protect the interest of developed countries. People infected with such diseases as AIDs cannot go beyond the trade barriers formed by drug patents for being unable to receive great treatment, thus affecting public health. Though the Doha Declaration later has clarified that it stands firmly with the interest of human beings when there is a conflict between human interest and 
economic benefit, there is still a huge gap in the governance of public health between the developed countries and developing ones. Moreover, the WTO seems to have widened the gap as it holds the concept that "profit above all else" making its governance function inadequate.

Though the WTO's objective lies in trade, its main purpose is still human welfare-based values including "promoting people's improvement of living standards" and "to ensure that developing countries have a share in the growth of international trade and promote their economic development". The WTO's general rules, (e.g. the "General Exceptions" to Article 21 of the General Agreement on Tariffs and Trade) allow public health issues to be the exceptions of free trade. Meanwhile, the WTO also harmonizes the conflict between free trade and public health governance by incorporating the rules and regulations of other international organizations into the various treaties to which it is a party. The third clause of the SPS Agreement has also clearly set out the principles for international coordination. The WTO also actively seeks information and suggestions from different international organizations to end any conflict. Besides, the WTO and WHO also work together to properly govern public health issues through positive communication and effective cooperation

Even so, the WTO mechanism still leaves most developing countries at a disadvantageous position, which has intensified the imbalance in public health governance and distribution of trade benefits. The imbalance will eventually lead to negative externalities of health governance worldwide. Therefore, developed countries among the States parties should take more responsibility in public health governance, including, but not limited to, the provision of better. public health products and lower tariff barriers for pharmaceuticals [6].

Table1. Specific Public Health Issues and Four WTO

\begin{tabular}{|c|c|c|c|c|}
\hline \multicolumn{1}{|c|}{ Agreements [7] } \\
$\begin{array}{c}\text { Public health } \\
\text { issues }\end{array}$ & $\begin{array}{c}\text { The } \\
\text { Agreement on } \\
\text { the } \\
\text { Application of } \\
\text { Sanitary and } \\
\text { Phytosanitary } \\
\text { Measures }\end{array}$ & $\begin{array}{c}\text { Agreement } \\
\text { on } \\
\text { Technical } \\
\text { Barriers to } \\
\text { Trade }\end{array}$ & $\begin{array}{c}\text { Agreement } \\
\text { on Trade- } \\
\text { Related } \\
\text { Aspects of } \\
\text { Intellectual } \\
\text { Property } \\
\text { Rights }\end{array}$ & $\begin{array}{c}\text { General } \\
\text { Agreement } \\
\text { on Trade } \\
\text { in Services }\end{array}$ \\
\hline $\begin{array}{c}\text { Infectious } \\
\text { disease control }\end{array}$ & Yes & Yes & & \\
\hline Food safety & Yes & & & \\
\hline $\begin{array}{c}\text { Tobacco } \\
\text { control }\end{array}$ & & Yes & Yes & Yes \\
\hline Environment & Yes & Yes & & \\
\hline $\begin{array}{c}\text { Drug } \\
\text { accessibility }\end{array}$ & & & Yes & \\
\hline Health services & Yes & & & Yes \\
\hline Biotechnology & Yes & Yes & Yes & \\
\hline $\begin{array}{c}\text { Information } \\
\text { Technology }\end{array}$ & & & Yes & \\
\hline $\begin{array}{c}\text { Traditional } \\
\text { Knowledge }\end{array}$ & & & Yes & \\
\hline
\end{tabular}

\subsection{International Human Right Mechanism and State Obligations in Public Health Governance}

Ever since the Universal Declaration of Human Rights was signed by all countries after the Second World War, the guarantee of human rights has been recognized by all countries in the world and the international human right mechanism has also gradually been established. In the Preamble, the United Nations Charter has clarified the purpose of protecting human rights: "Promote and encourage respect for human rights and for fundamental freedoms for all." The Universal Declaration of Human Rights has reflected the general consensus on human rights in the international community and guarantees that human right norms act as the obligation for contracting states. For instance, Article 30 of Universal Declaration of Human Rights provides Nothing in this Declaration may be interpreted as implying for any State, group or person any right to engage in any activity or to perform any act aimed at the destruction of any of the rights and freedoms set forth herein.

Human right also exerts an important influence on public health and the guarantee of human right also helps promote public health. When epidemic diseases occur on a large scale, it is important for States to guarantee the right of citizens to be informed in their public governance, i.e., the obligation of Governments to inform the public in a timely manner [8]. In addition, countries are required to observe the principle of non-discrimination in terms of migration freedom and shall not offer differentiated treatment based on health conditions.In terms of individual freedom, the government cannot randomly limit individual freedom of citizens. Thus, the quarantine during the outbreak of the pandemic will conflict with individual freedom of citizens, while some group rallies aiming at protecting citizens are unable to lodge citizens' group appeal to the government at key periods to prevent cross infection.Therefore, it can be seen that the human right guarantee is a "right-based" precautionary measure to cope with infectious diseases. [1]

International Covenant on Economic, Social and Cultural Rights (hereinafter referred to as "The Covenant") requires countries to take active actions to protect the human rights of their citizens, which means they have to ensure second-generation human rights are protected. Article 9 of The Covenant stipulates that The States Parties to the present Covenant recognize the right of everyone to social security, including social insurance [9]. However, many developing countries are not economically capable of providing high-quality public health services to their citizens. As a result, they need developed countries to provide assistance, which, unfortunately, rarely happens. On the one hand, though developed countries are obligated to help according to the International Human Rights Law, they not only seldom do so, but also often interfere in the internal affairs of developing countries. The reason is that the current standard for evaluating human rights centers around developed nations that hold political motives. On the other hand, international principles such as sovereign equality and reciprocity, are not recognized by Covenants on Human Rights. Developed countries evade their obligations to help developing nations under this pretext. In addition, Covenants on Human Rights has proposed the principle of non-discrimination in naming diseases without stigmatizing places, which means that naming diseases based on regions is prohibited. This can be shown in opposing the "Spanish Flu" and naming COVID-19 the "Chinese virus". 


\section{Improving the Implementation of State Obligations in Global Public Health Governance}

\subsection{Strengthening the Validity of International Law}

International Law has set a unified code of conduct for all countries and boosted the confidence of the subjects of International Law in building a peaceful and secure international community. However, in the struggle with state sovereignty, the International Law is in an "inferior position". It lacks a strict superior law enforcement agency; therefore, its performance must depend on the selfconsciousness of the States parties. As countries are different in development levels and pursuit of interests, they may still not be able to fulfill the agreement even a cooperation treaty is signed.

Therefore, the dilemma of international law in global public governance can be addressed in the following ways.Firstly, mechanisms should be put in place to guarantee the fulfilment of obligations. For example, by establishing a stronger focal point to which every country can keep in touch and report their latest information. As such, all countries can share information on epidemic more effectively and comprehensively and conduct better international cooperation through effective information sharing [3]. Secondly, all countries should take precautionary measures according to the recommendation and properly expand the power of such international organizations as the WHO so that their suggestions are more valid for all countries. Meanwhile, a monitoring mechanism should be established to recommend that States fulfill their obligations when they act in violation of international conventions or threaten international peace and security.

\subsection{Improvement of Domestic Legislation}

The limitations of International Law require countries to strengthen the rule of law. The concept of the rule of law is fully embodied in the Charter of the United Nations, which represents a universal and inalienable value of the United Nations. Good law and governance stand at the core of rule of law in modern society, which requires countries to beef up domestic legislation on public health governance in the first place, especially in the field of human rights. In the governance of the COVID-19 epidemic and other infectious diseases, the personal freedom and privacy rights of patients infected with the virus have been improperly violated. Therefore, it is required that the central authority pass legislation to regulate the behavior of governments and protect people's rights from from creating jobs to providing medical facilities. Secondly, all countries should step up efforts to legislate on health care and social welfare and protect people's freedom of expression so that citizens' concerns can be promptly addressed by the government and the legal system can be constantly perfected and enriched. Aside from the improvement of relevant laws, public institutions should also rationally manage public expenditure, guarantee the input of public health facilities, and effectively manage public health facilities.

\subsection{Establish the Value of "Community with a Shared Future for Mankind"}

In the past practice of global public health governance, even though many international treaties have been signed among countries, for the sake of their own state interests, they failed to fully fulfill their obligations under the agreements. The misalignment of actions arises from the lack of ideological inconsistency. To better the undesirable governance system also requires the guidance of concepts. The "community with a shared future for humanity" proposed by China offers guidance for promoting cooperation on global public health governance. This concept is rooted in Chinese traditional Confucianism and emphasizes universal harmony.

In the international society, there is a theoretical and practical basis for the concept of community. First of all, "peace, development, equity, justice, democracy and freedom" are the lofty goals of the United Nations and the common values of all mankind [7]. Also, as sovereign states become more interdependent, the concept of the international community is being cited more frequently. For example, the Vienna Convention on the Law of Treaties stipulates that a treaty is void if it conflicts with a peremptory norm of International Law. In other words, certain states are not allowed to act in a self-serving way that undermines the interest of the international community. Additionally, international jurists have long been studying the concept of community. Hugo Grotius believed that the code of conduct formulated by communities can prevent international conflicts and promote international cooperation to a certain extent.

The conception of a human community with a shared future is monumental in fulfilling the obligations of international society. This not only means a methodological shift in International Law from individualism to collectivism, but also provides a philosophical answer to those questioning the legitimacy of International Law. The concept of a human community with a shared future goes beyond the basis for the fulfillment of international obligations that underlines states" "voluntarism". As a result, every state becomes bound by matters of great concern and universal requirements, which urges parties involved in global public health governance to reach a consensus on carrying out their obligations. Then obligations specified by international treaties can be honored more efficiently.

\section{Conclusion}

Global public health is an issue brought by the global economic development. Better public health governance will certainly boost economic development while poor public health governance will substantially lower the life quality of the whole human race. While recognizing the defects in the current governance system, countries should try to construct a perfect public health system in which international obligations are fulfilled, international 
cooperation is constantly strengthened, and international community can achieve common development. Global public health governance has a long way to go. In face of unknown problems in the future, countries should be fully courageous and confident in coping with challenges. We should not give up our ideals for reality, nor should we give up pursuit owing to our ideals.

\section{References}

1. A. Kiss and D. L. Shelton, "Guide to International Environmental Law," Social Science Electronic Publishing, vol. 17, no. 3, pp. 351-353, 2007.

2. M. Ragazz, The Concept of International Obligations Erga Omnes, Beijing: Law Press · China, 2013.

3. S. Y. Sun, The Obligations of State Parties Under the International Covenant on Civil and Political Rights, Beijing: Social Sciences Academic Press (China), 2012.

4. G. P. Rao, "On the Relationship Between International Organizations and Law of International Organizations," Peking University Law Journal, no. 1, pp. 68-75.

5. J. Crawford, Brownlie's principles of public international law, Beijing: Law Press · China, 2019.

6. H. W. Liu, On the On the Asymmetry of State Obligations Under the International Covenant on Economic, Social and Cultural Rights, Beijing: Peking University Press, 2005.

7. G. P. Rao, “Ontology, Object and Scope: Discussion of the Basic Problems on the Discipline of Law of International Organizations," Chinese Review of International law, no. 1, pp. 62-73.

8. X. M. Wang, State Obligations to the International Community as a Whole, Beijing: Law Press China, 2009.

9. T. Y. Wang, Introduction to International Law, Beijing: Peking University Press, 1998.

10. N. S. Malcolm, International Law, Beijing: Peking University Press, 2005. 